\title{
$\mathrm{SCM}$ 에 $\mathrm{MFCA}$ 를 적용하기 위한 개념 연구
}

\author{
장 정 환 ${ }^{*}$ 장 청 윤 ${ }^{*}$ 장 승 연 ${ }^{*}$-조 용 철 ${ }^{* *}$ 이 현 근 ${ }^{* *}$ - 이 창 호* \\ *인하대학교 산업 공학과 - ${ }^{* *}$ 한국항만연수원 인천연수원 \\ ***엘비세미콘
}

\section{A Study on Concept Development of MFCA Application for SCM

\author{
Jung-Hwan Jang ${ }^{*} \cdot$ Jing-Lun Zhang ${ }^{*} \cdot$ Yong-chul Jho ${ }^{* *} \cdot$ Hyun-Keun Lee ${ }^{* * *} \cdot$ Chang-ho Lee ${ }^{*}$ \\ ${ }^{*}$ Department of Industrial Engineering, INHA University \\ ${ }^{* *}$ Korea Port Training Institute Incheon $\cdot{ }^{* * *} \mathrm{LB}$ Semicon
}

\begin{abstract}
The importance of environmental protection has been increased recently. Thus the environmental management was settled in an important global competition factor. In the meantime logistics cost occupied the $8.03 \%$ of sales at 2011. This portion was greater than the portion of other countries and it was needed the reduction of logistics cost to secure the competition power. As thus in this paper we prepared the process which diminish the environmental discharge and decrease the logistics cost. We proposed the process to apply the MFCA to SCM, until now the MFCA had been used generally in manufacturing process. We defined the loss in SCM and the plus logistic, minus logistic, logistic center and the classification of cost to adopt the MFCA to SCM. Keywords : MFCA, Plus logistics, Minus logistics, Logistics Center
\end{abstract}

\section{1. 서 론}

최근 전 세계적으로 환경보전의 중요성이 급증하면 서, 환경경영은 기업의 국제경쟁력을 확보하는데 중요 한 요인으로 자리를 잡고 있다. 우리나라는 교토의정서 상에서 개발도상국으로 분류되어 1 차 공약기간에는 온 실가스 감축의무가 면제되었으나, 2013년부터 모든 가 입 국가들에게 온실가스 감축의무를 부과하는 발리로 드맵(2007)에 의하여 우리나라 또한 온실가스 감축 의 무 부담에 대한 압력을 크게 받을 것으로 예상된다[6].

한편 2011년도 제조업 및 도소매업의 매출액 대비 물 류비 비중은 $8.03 \%$ 로 나타났다[8]. 기능별 국가 물류비
추이를 보면 재고유지관리비(16.74\%), 하역비(16.38\%), 포장비(14.23\%), 수송비(12.69\%), 물류정보관리비(11.88\%) 순으로 증가율이 높게 나타났다[2]. 이 수치는 주요 선 진국의 매출액 대비 물류비용에 비해 높게 나타나 경쟁 력 확보를 위해 물류비 절감이 필요함을 확인할 수 있 다. 물류비절감은 매출액의 증대로 바로 이어질 수 있 는 시사점을 가지고 있기 때문에 운송비 및 포장비 등 전체적인 물류비의 절감이 필요한 시점이다.

이렇게 환경의 중요성과 물류비 절감에 대한 필요성 이 부각되고 있지만 환경부하 감소를 위한 활동은 코 스트를 증가시킨다는 인식이 지배적이다. 따라서 환경 부하와 물류원가를 절감할 수 있는 방안이 필요하다.

† Corresponding Author : Chang-Ho Lee, Industrial Engineering, INHA UNIVERSITY, 100, inha-ro, Nam-gu, Incheon, M • P : 010-3761-2995, E-mail: 1ch5601@inha.ac.kr Received October 20, 2013; Revision Received December 5, 2013; Accepted December 5, 2013. 
본 논문에서는 환경부하와 물류원가를 절감할 수 있 는 방안으로서 제조업에서 활용되고 있는 $\mathrm{MFCA}$ 방법 을 $\mathrm{SCM}$ 에 적용하기 위한 연구를 진행하고자 한다.

\section{2. 이론적 배경}

\subsection{MFCA}

MFCA(Material Flow Cost Accounting)란 생산 공 정 또는 제품 전 과정의 각 단계에 투입된 물질과 그 로부터 산출된 제품(양품) 및 손실에 대한 원가를 파악 하여 원가절감과 동시에 자원의 손실을 최소화하기 위 한 관리기법이다. MFCA에서는 원재료와 자재 등과 같 은 재료의 흐름과 재고를 물량과 금액의 양 측면에서 측정한다. 이를 등식으로 나타내면 다음과 같은 시스템 으로 된 것을 확인할 수 있다.

$\mathrm{MFCA}$ (물질흐름 원가회계)

$=\mathrm{MFA}($ Material Flow Analysis, 물질흐름분석 $)+$

\section{Cost Management System}

$\mathrm{MFCA}$ 의 기본구조로는 [Figure 1]과 같이 $\mathrm{MFCA}$ 계산상의 단위인 물량센터, 다음의 공정에 투입되는 물 량이 되는 정(正)의 제품 그리고 폐기되거나 다음의 공 정에 투입되지 않는 물량인 부(負)의 제품으로 분류를 한다[6].

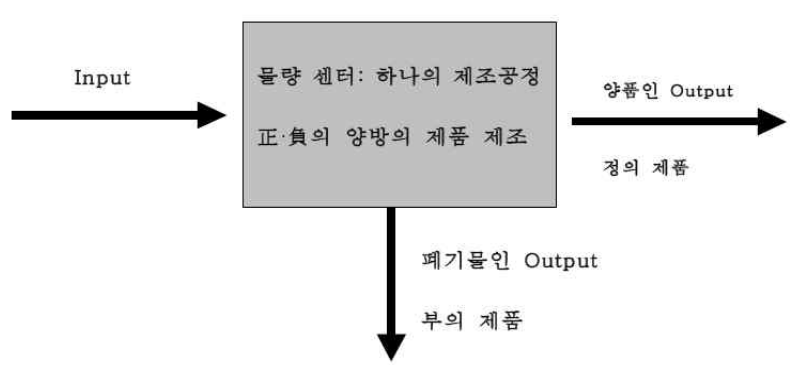

[Figure 1] MFCA in the manufacturing process

$\mathrm{MFCA}$ 의 원가 구분은 크게 3 가지로 할 수 있다. 첫 째, $\mathrm{MC}($ Material Cost)라는 카테고리다. $\mathrm{MC}$ 의 예로는 원재료, 부재료, 용수 등이 있다. 둘째, $\mathrm{SC}$ (System Cost)인데 이것의 예로는 감가상각비, 노무비, 수선유지 비 등이 있다. 마지막으로는 UC(Utility Cost)이며 그 예로는 전력, 중유, 천연가스 등이 있다[6].

\section{2 물류원가}

제조업에서 사용되는 $\mathrm{MFCA}$ 방법을 이용하기 위해 서는 제품 제작에 필요한 물질들의 원가와 흐름에 대
한 이해가 필요하다. 이와 같이 $\mathrm{SCM}$ 에 $\mathrm{MFCA}$ 방법을 적용하기 위해서는 물류원가에 대한 이해가 선행되어 야한다.

국토해양부고시 제2012-533호의 기업물류비 산정지침 에서는 물류를 재화가 공급자로부터 조달·생산되어 수 요자에게 전달되거나 소비자로부터 회수되어 폐기될 때 까지 이루어지는 운송·보관·하역(荷役) 등과 이에 부가 되어 가치를 창출하는 가공·조립·분류·수리·포장·상표부 착·판매·정보통신 등의 제 활동으로 정의하고 있다. 이 어서 물류비는 앞에서 정의된 물류활동을 수행하기 위 하여 발생하거나 소비한 경제가치로 정의하고 있다[1].

한국생산성본부의 기업물류비 계산준칙에서는 물류비 를 특정 제조업자의 제조와 판매활동(유통업자의 경우 유통과 판매활동)에 수반되는 물류활동을 수행하기 위 하여 발생하거나 소비한 경제 가치로 정의하고 있다[5].

한국교통연구원에서는 물류비의 개념을 국가물류비 와 기업물류비로 나누어 정의하고 있다. 국가물류비는 국가경제 내에서 물류활동을 통해 수송비, 재고유지관 리비, 포장비, 하역비, 물류정보비, 일반관리비 등의 형 태로 지출된 총비용을 말한다. 기업물류비는 화주기업 이 기업활동을 영위하는 과정에 물류활동을 위해 지출 한 비용을 말한다[2]. [Figure 2]는 국가 물류비의 범위 를 보여준다.

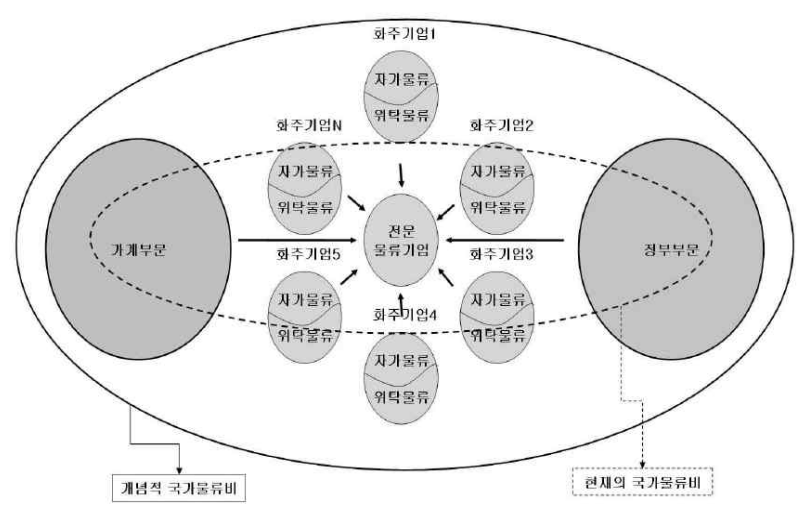

[Figure 2] Range of national distribution costs

이와 같이 물류비라고 할 수 있는 것은 물류활동을 수행하면서 발생하는 비용이라고 할 수 있다. 이러한 물류비의 원가 항목들에 대해서는 기업물류비 산정지 침을 통해 파악할 수 있다.

\subsection{1 영역별 물류비}

영역별 물류비는 조달물류비와 사내물류비, 판매물류 비, 리버스(Reverse)물류비로 분류된다. 영역별 물류비 계산의 효익으로는 물품의 영역별 이동에 따른 물류의 흐름과 비용의 흐름을 파악하고, 물품의 이동 상황에 맞 
춘 비용 파악을 통해 물류비 절감 부분을 파악할 수 있 으며, 물품의 이동 상황에 맞춘 물류업무의 문제점과 이 에 관한 효율증대 방안을 강구할 수 있는 점이 있다[2].

조달물류비는 물자의 조달처로부터 운송되어 매입자의 보관창고에 입고, 관리되어 생산공정(또는 공장)에 투입 되기 직전까지의 물류활동에 따른 물류비를 말한다[1].

사내물류비는 매입물자의 보관창고에 완제품 등의 판매를 위한 장소까지의 물류활동에 따른 비용을 말한 다. 다만 재료의 생산이나 제품의 제조공정 내에서 발 생하는 비용은 생산원가 또는 재조원가에 산입되므로 물류비에서는 제외시킨다[1].

판매물류비는 생산된 완제품 또는 매입한 상품을 판 매창고에서 보관하는 활동부터 고객에게 인도될 때까 지의 물류비를 말한다[1].

리버스(Reverse)물류비는 회수물류비, 폐기물류비, 반 품물류비로 세분화한다. 회수물류비란 공용기와 포장자 재 등이 회수되어 재사용 가능할 때까지의 물류비를 말한다. 폐기물류비란 제품이나 상품, 포장용 또는 수 송용 용기나 자재 등을 회수하여 폐기할 때까지의 물 류비를 말한다. 반품물류비란 판매한 제품·상품 또는 위탁판매한 제품·상품의 취소, 위탁의 취소 등의 물류 활동에 따른 물류비를 말한다[1].

\subsection{2 기능별 물류비}

기능별 물류비는 운송비, 보관비, 포장비, 하역비, 물 류정보·관리비로 분류된다. 기능별로 물류비를 계산하 면 물류관리조직이 기능별로 편성되어 있을 경우 비용 에 대한 책임 소재 등의 파악과 관련하여 매우 중요하 기도 하지만, 물류기능별 채산분석을 하여 물류비 절감 목표를 설정한 경우 어느 기능에서 얼마정도 절감이 가능한가를 나타낼 수 있다[2].

운송비는 물자를 물류거점 간 및 고객에게 이동시키 는 활동에 따른 물류비를 말한다. 다만, 개별기업의 물 류비 계산목적에 따라 다음과 같이 세분화할 수 있다. 수송비는 기업의 필요에 따라 물자를 물류거점까지 이 동시키는 물류비를 말한다. 배송비는 물자를 고객에게 배달시키는 물류비를 말한다.

보관비는 물자를 창고 등의 물류시설에 보관하는 활 동에 따른 물류비를 말한다[1].

하역비는 유통가공 및 운송, 보관, 포장 등의 업무에 수반하여 상차 및 하자, 피킹, 분류 등 물자를 상하·좌 우로 이동시키는 물류비를 말한다[1].

포장비는 물자 이동과 보관을 용이하게 하기 위하여 실 시하는 상자, 골판지, 파렛트 등의 물류포장(최종소비자를 위한 판매포장은 제외)활동에 따른 물류비를 말한다[1].
물류정보·관리비는 물류활동 및 물류기능과 관련된 정 보처리와 관리에 따른 물류비를 말한다. 다만, 개별기 업의 물류비 계산목적에 따라 다음과 같이 세분화할 수 있다. 물류정보비는 구매, 수송, 생산, 창고운영, 재 고관리, 유통망 등 물류 프로세스를 전략적으로 관리하 고 효율화하기 위하여 컴퓨터 등의 전자적 수단을 사 용하여 지원하는 활동에 따른 물류비를 말한다. 물류관 리비는 물류활동 및 물류기능의 합리화와 공동화를 위 하여 계획, 조정, 통제 등의 물류관리 활동에 따른 물 류비를 말한다[1].

\section{$2.3 \mathrm{SCM}$ 에 $\mathrm{MFCA}$ 도입 사례}

\subsection{1 국내사례}

국내 사례로는 디지털방송 수신기 판매 업체인 $\mathrm{H}$ 사 의 사례가 있다. $\mathrm{H}$ 사는 공급사슬 상에서 모기업으로써 영업을 담당하고 있으며 $\mathrm{S}$ 사와 $\mathrm{Y}$ 사에서 생산한 부품 을 $\mathrm{D}$ 사가 조립하여 $\mathrm{H}$ 사에 납품하는 형태의 협력관계 를 구축하고 있다. 분석 대상 제품을 선정하여 $\mathrm{SCM}$ 상에 있는 $\mathrm{S}$ 사( $\mathrm{F} / \mathrm{Panel}$ 제작 납품), Y사(Top Cover, Bottom Cover 제작 납품), $\mathrm{D}$ 사(S사와 $\mathrm{Y}$ 사에서 생산한 부품들을 납품 받아 조립)의 물질의 흐름과 원가정보를 수집하여 MFCA 방법으로 분석하였다.

기존에 각 협력사의 불량률(모기업과 협력사들이 실 제로 알고 있는 불량률)은 $\mathrm{S}$ 사( $1.3 \%), \mathrm{Y}$ 사(0.5\%), $\mathrm{D}$ 사 (0.3\%)이내로 관리되고 있으나 모기업 입장에서는 전 체 손실이 얼마인지는 모르는 상황이었다.

$<$ Table 2> MFCA result of the application of the Company $\mathrm{H}$

\begin{tabular}{|c|c|c|c|c|c|}
\hline \multirow[b]{2}{*}{ 구분 } & \multirow{2}{*}{$\begin{array}{l}\text { 관리 } \\
\text { 지표 }\end{array}$} & \multicolumn{3}{|c|}{ 협력기업 } & \multirow{2}{*}{$\begin{array}{l}\text { 모기업 } \\
\mathrm{H} \text { 사 }\end{array}$} \\
\hline & & $\mathrm{S}$ 사 & $\mathrm{Y}$ 사 & $\mathrm{D}$ 사 & \\
\hline $\begin{array}{l}\mathrm{MFCA} \\
\text { 적용 전 }\end{array}$ & $\begin{array}{c}\text { 불량 } \\
\text { 률 }\end{array}$ & $1.3 \%$ & $0.5 \%$ & $0.3 \%$ & 모름 \\
\hline \multirow{2}{*}{$\begin{array}{l}\mathrm{MFCA} \\
\text { 적용 후 }\end{array}$} & $\begin{array}{c}\text { Loss } \\
\text { 율 }\end{array}$ & $2.35 \%$ & 약6\% & $0.58 \%$ & $1.58 \%$ \\
\hline & $\begin{array}{l}\text { Loss } \\
\text { 금액 }\end{array}$ & 565,825 & 93,759 & 145,515 & 805,099 \\
\hline
\end{tabular}


하지만 MFCA 방법을 적용한 분석결과 <Table 1> 과 같이 각 회사는 $2.35 \%, 6 \%, 0.58 \%$ 로 적용 전보다 훨씬 많은 loss율을 확인 할 수 있었고 $\mathrm{H}$ 사 역시 이런 정보를 토대로 관리지표를 만들 수 있었다.

이를 통해 세 가지의 결론을 얻을 수 있다. 첫째, 공 급업체와 공동으로 개선활동에 대처할 수 있으며, 둘째, 물질흐름을 거래기업 간 또는 공급사슬에서 접근함으 로써 개별 회사만을 대상으로 하는 경우와 달리 공급 사슬 전체의 관점에서 의사결정이 가능하게 되며, 셋째, 기업 간에 존재하는 재고를 물질흐름으로서 파악하는 것이 가능하게 되었다[9].

국내의 $\mathrm{SCM}$ 에 $\mathrm{MFCA}$ 도입 사례 조사 결과에서는 제조공정에 적용한 $\mathrm{MFCA}$ 를 모기업과 협력기업으로 확대하여 적용한 사례만을 확인하였으며, 물류에 적용 한 사례는 없는 것으로 파악 되었다.

\subsection{2 해외사례}

일본의 군제 주식회사는 어패럴 사업, 및 플라스틱 필름 등의 기능 자재 관련 사업을 하고 있다. 군제 주 식회사에서 주로 발생하는 loss는 고객에게 팔리지 않 고 남은 상품의 반품, $\mathrm{DC}($ Distribition Center)에서 불 량 재고로 모인 상품을 $\mathrm{LC}$ (Logistics Center)로 되돌리 는 반송, $\mathrm{DC}$ 나 $\mathrm{LC}$ 의 외부창고에 이송하거나 되돌리거 나 하는 센터 간 이동 물류 등이 있다. 이 과정에 수송 의 연료(에너지)를 쓸데없이 소비하는 것이 확인되었 다. 그래서 이번 물류 $\mathrm{MFCA}$ 적용 실험에서는 통상의 제조 $\mathrm{MFCA}$ 로 이용하고 있는 정의 제품, 부의 제품의 개념에 추가하여 정의 물류(고객을 향하는 것의 흐름), 부의 물류(반품 등 고객을 향하지 않는 것의 흐름)의 개념을 도입하여 로스를 명확하게 하는 수법을 연구했 다. [Figure 3]은 그것의 개념도를 나타낸다.

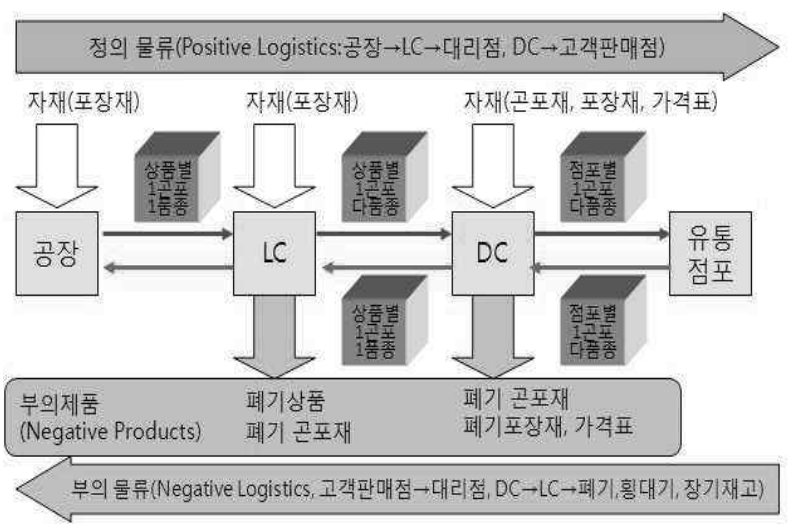

[Figure 3] MFCA conceptual diagram of logistics Gunze Co., Ltd.
데이터 수집은 2004년도 1 년간의 데이터를 수집하 였고 데이터는 물류 수량(기초재고, 기말재고, 입하수 량, 출하수량, 폐기 상품의 수량), 판매실적 단가, 판매 기준 단가 그리고 물류 경비 등을 수집하였다. 이와 같 이 정의 물류 및 부의 물류 개념을 반영하면 물류 코 스트 로스는 <Table2>와 같이 $25.91 \%$ 로 물류의 로스 가 명확하게 되는 것을 확인할 수 있었다[4].

$<$ Table 3> MFCA result of the application of the Gunze Co., Ltd.

\begin{tabular}{|c|c|c|c|}
\hline & $\begin{array}{c}\text { 정의 물류 } \\
\text { System } \\
\text { Cost }\end{array}$ & $\begin{array}{c}\text { 부의 물류 } \\
\text { System } \\
\text { Cost }\end{array}$ & 계 \\
\hline $\begin{array}{c}\text { 양품 } \\
\text { (Positive } \\
\text { Products) }\end{array}$ & 192,986 & 67,493 & 260,478 \\
\cline { 2 - 4 } & $74.09 \%$ & $25.91 \%$ & $100.0 \%$ \\
\hline $\begin{array}{c}\text { Material Loss } \\
\text { (Negative } \\
\text { Products) }\end{array}$ & 0 & 0 & - \\
\cline { 2 - 4 } 폐기/Recycle & $-.00 \%$ & $0.00 \%$ & $0.00 \%$ \\
\cline { 2 - 4 } & - & - & - \\
\hline \multirow{2}{*}{ 소계 } & 192,986 & 67.493 & 260,479 \\
\cline { 2 - 4 } & $74.1 \%$ & $25.9 \%$ & $100.0 \%$ \\
\hline
\end{tabular}

\section{3. $\mathrm{SCM}$ 에 $\mathrm{MFCA}$ 도입을 위한 방법론}

\section{1 물류 낭비의 유형}

첫 번째, 상품폐기의 문제가 있다. 상품의 포장과 보 관 및 운송 단계에서 손상되거나, 상품이 사용기한이 있는 경우 재고가 장기화되면 상품의 가치가 없어져 폐기해야하는 경우가 발생한다. 또한 포장의 파손과 포 장단위의 변경에 따른 재포장으로 인해 발생하는 낭비 가 있다.

두 번째, 낭비 수송의 문제가 있다. 창고 내에서 불 필요한 이동이나 물류센터 간 이동과 같은 수송의 낭 비가 발생할 수 있다.

세 번째, 자원과 자금의 정체가 있다. 구입한 원재료나 상품이 장기간 재고로 남아 자금융통을 악화시키는 문제 와 디자인요소가 큰 상품, 기술혁신이 빠른 분야의 상품 은 재고 기간이 길어지면 본래의 상품가치를 잃게 된다.

따라서 궁극적으로는 이러한 문제점으로 인한 낭비 의 발생을 줄이기 위해 상품 폐기의 제로화와 불필요 한 물류의 제로화, 재고의 제로화를 달성하기 위한 방 안이 필요하다[4]. 


\section{$3.2 \mathrm{SCM}$ 에 $\mathrm{MFCA}$ 도입을 위한 정의}

일본의 군제 주식회사의 경우 $\mathrm{SCM}$ 상에서 발생하는 낭비를 줄이기 위한 방안으로 $\mathrm{MFCA}$ 방법론을 시범 적용한 사례가 있다. 이 사례에서는 정의 물류를 고객 에게 향하는 물류로 정의하였고, 그 이외의 물류 흐름 은 부의 물류라 하여 낭비로 정의하였다. 하지만 $\mathrm{SCM}$ 상에서 이러한 정의로 정과 부의 물류를 일괄적으로 정의하는 데에는 문제점이 있다.

공급사슬 상에는 다수의 공급기업과 제조기업, 고객 들이 있다. 공급사슬 구성원간의 물류활동을 영역별로 구분하였을 경우 공급기업과 제조기업간에는 조달물류 와 리버스물류가 이루어질 것이다. 제조기업과 고객 간 에는 판매물류와 리버스물류가 이루어지며, 제조기업 내에서는 사내물류가 이루어진다. 이와 같이 공급사슬 상의 구성간의 물류활동은 물류활동의 목적에 따라 달 라지며, 물류비 계산에 있어서도 서로 다른 방법을 사 용한다. 특히 리버스물류의 경우 무조건 낭비라고 판단 해서는 $\mathrm{SCM}$ 상의 정확한 물류낭비 측정을 저해할 수 있다. 따라서 영역별 물류의 종류에 따라 각기 다른 정 의 물류와 부의 물류 그리고 낭비의 정의가 필요하다.

\section{2 .1 조달물류에서 부의 물류의 정의}

조달물류는 공급자로부터 물자의 조달, 구매과정에서 발생하는 운송, 보관, 하역, 포장 등의 물류활동이다. 국내 조달물류의 특징으로는 조달처에서 매입물자에 대한 운송비 등을 부담하기 때문에 타사지불물류비의 산정을 위한 검증가능성과 객관성 등이 취약하여 실제 물류비 계산에서는 제외하고 있다. 조달물류에서의 물 류활동으로는 자재를 보관하고 제조업체로 납품하기 위한 포장과 하역, 검수, 출고, 운송 그리고 제조업체에 서의 하역과 검수, 보관활동 등이 있다. 조달물류의 흐 름은 [Figure 4]와 같다.

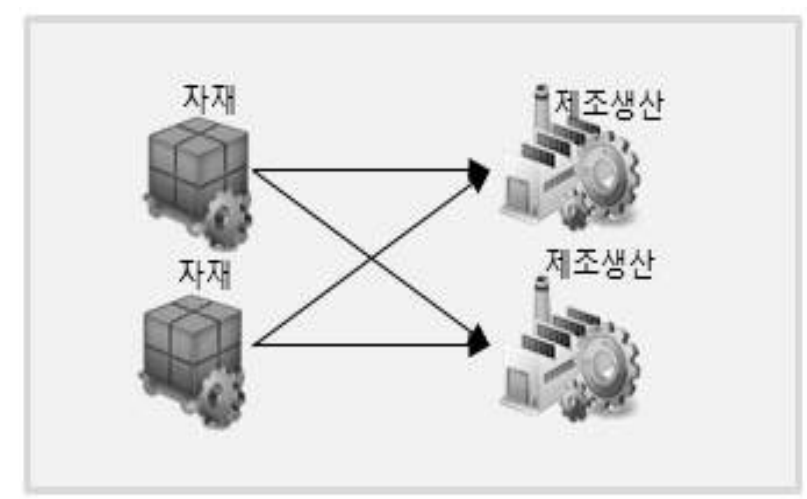

[Figure 4] Flow of procurement logistics
이러한 조달물류의 목적은 원재료나 부품 등의 매입 물자가 매입처에 정상적으로 도착하여 생산에 투입되 는 것이다. 따라서 조달물류의 목적에 맞지 않는 물류 활동은 부의 물류라 정의할 수 있다. 조달물류에서의 부의 물류는 다음과 같다.

\section{재고: 필요 이상의 재고품 보관}

배송지연: 매입처에 정시 납품을 못할 경우 발생하는 손해

반송: 매입처의 검수과정에서 발견된 불량 등

폐기물: 포장재 및 파손품과 상품가치가 떨어진 장기 재고품 등의 폐기

\section{2 .2 사내물류에서 부의 물류의 정의}

사내물류는 제조 또는 생산 그리고 제조과정 외에 가 공공정에서 발생하는 공장 내 또는 공장 간의 운송, 보 관, 하역 등의 물류활동이다. 사내물류에서는 재료의 생산이나 제조공정에서 발생하는 비용은 생산원가 또 는 제조원가에 삽입되므로 물류비에서는 제외한다. 따 라서 사내물류에서 물류활동은 이를 제외한 조달보관 창고에서 생산라인으로의 이동과 공장 간의 이동 그리 고 공장에서 완제품 창고까지의 이동과 물류창고로의 이동에 필요한 포장, 운송, 하역, 보관 등의 활동이 있 다. 사내물류의 흐름은 [Figure 5]와 같다.

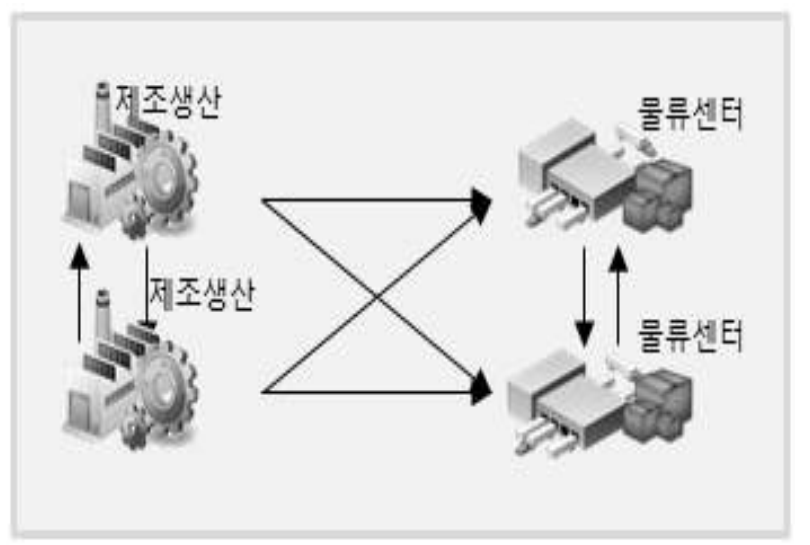

[Figure 5] Flow of internal logistics

사내물류 역시 조달물류와 마찬가지로 사내물류의 목적에 맞지 않는 물류활동을 부의물류라 정의할 수 있다. 사내물류에서의 부의 물류는 다음과 같이 정의할 수 있다.

재고: 필요 이상의 재고품 보관

폐기물: 포장재 및 파손품과 상품가치가 떨어진 장기 재고품 등의 폐기 


\subsection{3 판매물류에서 부의 물류의 정의}

판매물류는 수요자에게 물자를 전달하기 위해 발생 하는 운송, 보관, 하역 등의 물류활동이다. 판매물류는 생산된 완제품 또는 매입한 상품을 판매창고에 보관에 서부터 고객에게 인도될 때까지의 과정이 있다. 판매물 류에서 물류활동으로는 판매창고에서의 보관과 상품의 피킹, 출고, 상차와 고객으로의 운송, 하차 등의 활동이 있다. 판매물류의 흐름은 [Figure 6]과 같다.

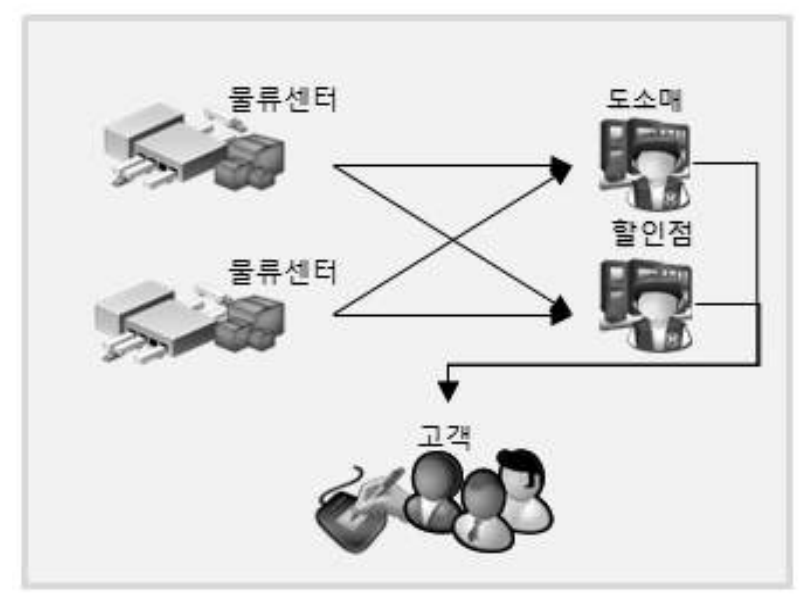

[Figure 6] Flow of sales logistics

판매물류 역시 다른 영역별 물류와 마찬가지로 판매 물류의 목적에 맞지 않는 물류활동을 부의 물류로 정의 할 수 있다. 판매물류에서의 부의 물류는 다음과 같다.

재고: 필요 이상의 재고품 보관

배송지연: 매입처에 정시 납품을 못할 경우 발생하는 손해

반송: 매입처의 검수과정에서 발견된 불량 등

폐기물: 포장재 및 파손품과 상품가치가 떨어진 장기 재고품 등의 폐기

\subsection{4 리버스물류에서 부의 물류의 정의}

리버스물류는 판매물류 이후에 발생하는 반품, 폐기, 회수 과정에서 발생하는 물류활동을 말한다. 리버스물 류는 판매물류 이후라고 하지만 판매에 주체에 따라 달 라지기 때문에 출하처(소비자 포함)에서 반송, 반품 되 는 물류와 용기를 재사용하기 위한 회수, 제품을 재자 원화하기 위한 리사이클 물류라 할 수 있다. 따라서 리 버스물류는 조달물류와 사내물류, 판매물류에서 모두 이루어지는 물류활동이다. 최근 홈쇼핑과 인터넷 판매 의 활성화로 인해 반품이 필수적인 상황이며, 용기의 회수를 통한 재사용과 리사이클에 이용하여 이윤을 창 출하고 있기 때문에 리버스물류 자체를 부의 물류로 정
의할 수 없다. 리버스물류의 흐름은 [Figure 7]과 같다.

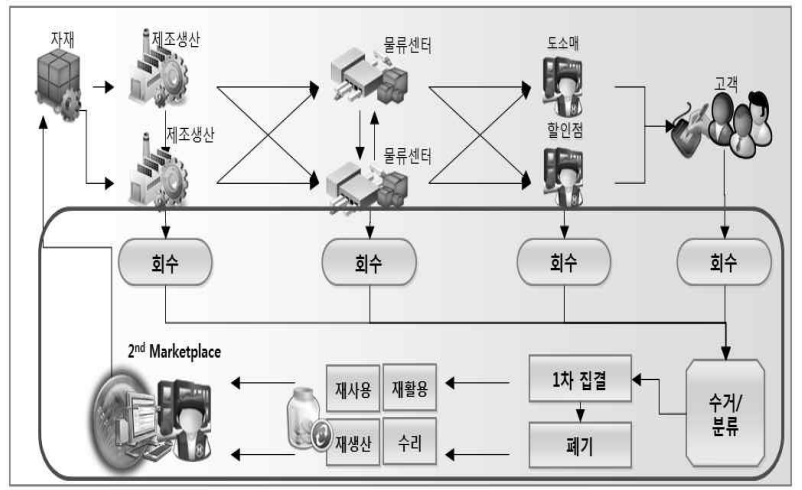

[Figure 7] Flow of reverse logistics

리버스물류 역시 다른 영역별 물류와 마찬가지로 리버 스물류의 목적에 맞지 않는 물류활동을 부의 물류로 정의 할 수 있다. 리버스물류에서의 부의 물류는 다음과 같다.

재고: 반품 및 폐품의 장기 보관

폐용기: 재사용이 불가능한 파손된 용기

폐기품: 리사이클이 불가능한 반품 및 폐품

\section{2 .5 물량센터와 코스트의 정의}

앞서 정의된 바와 같이 $\mathrm{SCM}$ 에서 $\mathrm{MFCA}$ 사고방식을 적용한 정의 물류는 물류영역별 목적에 맞는 물류활동 이라 정의할 수 있으며, 반대로 부의 물류는 물류영역 별 목적에 맞지 않는 물류활동이라고 정의할 수 있다. 또한 영역별 물류에서 발생할 수 있는 로스를 정의하 였으나 보다 정확한 부의 물류 파악을 위해서는 제시 된 로스 이외에 로스가 발생하는 부분에 대한 지속적 인 업데이트가 필요하다.

다음으로는 $\mathrm{MFCA}$ 방법에서 원가측정의 중심이 되 는 물량센터의 지정이 필요하다. 공급사슬에서 물량센 터는 공급사슬에서 각각의 구성원이 될 수 있다. 필요 에 따라 더욱 세분화하여 각각의 구성원 내에서 이루 어지는 운송, 포장, 하역 등의 활동을 물량센터로 지정 할 수도 있지만 세분화할수록 더욱 복잡한 계산과정과 추정방법이 필요하다.

물량센터 이외에도 $\mathrm{MFCA}$ 방법에서의 $\mathrm{MC}, \mathrm{SC}, \mathrm{EC}$ 에 대한 정의가 필요하다. 기존 제조업에서의 $\mathrm{MFCA}$ 에 서는 코스트의 구분을 $\mathrm{MC}, \mathrm{SC}, \mathrm{EC}$ 로 정의하였으며 각 각의 코스트에 대한 정의와 구분이 명확하다. 기존의 방법에서는 $\mathrm{MC}$ 를 원재료, 부재료 용수 등으로 정의하 였고, $\mathrm{SC}$ 를 감가상각비, 노무비, 수선유지비 등으로 정 의하였으며, $\mathrm{EC}$ 를 전력, 중유, 천연가스 등의 에너지원 으로 정의하였다. 물류활동에서 원재료라고 할 수 있는 부분은 자재 또는 제품과 같은 운송품이 될 수 있으며, 
부재료로써 포장재들이 $\mathrm{MC}$ 에 해당될 수 있다. 물류활 동에서 $\mathrm{SC}$ 는 제조업의 경우와 동일한 감가상각비, 노 무비, 수선유지비 등이 해당된다. $\mathrm{EC}$ 또한 제조업의 경 우와 비슷한 물류시설과 운송수단 등에 필요한 에너지 원이 해당된다. $\mathrm{MC}$ 와 $\mathrm{SC}, \mathrm{EC}$ 는 기존의 물류 수량 등 의 물동량 데이터와 기업물류비 산정지침에 따른 물류 원가 데이터를 활용할 수 있다. 예를 들어 정해진 시간 에 정해진 수량의 제품이 이상 없이 배송되고, 포장의 교체가 없으며, 물류영역별 목적에 맞는 물류활동 만이 이루어 졌다면 부의 물류는 없다고 할 수 있다.

\section{$3.3 \mathrm{SCM}$ 에 $\mathrm{MFCA}$ 도입 방안}

앞의 내용을 통해 $\mathrm{SCM}$ 에 $\mathrm{MFCA}$ 방법을 적용하기 위한 기본적인 정의들을 확인하였다.

도입방안은 [Figure 8]을 통해 설명할 수 있다. SCM 을 단순화하였을 때 원자재나 부품의 조달처와 제조생 산업체, 물류센터, 도소매점 및 할인점 그리고 소비자 로 구성된다. 또한 $\mathrm{SCM}$ 상의 반송 및 반품 등 리버스 물류활동은 모든 구성원들에서 발생한다고 할 수 있다.

[Figure 8]의 1 번 6 번 사이의 물류 흐름에서 1 번과 2 번 사이에는 조달물류와 필요에 따라 6 번의 리버스 물류활동이 이루어진다. 이와 같은 흐름에서 $\mathrm{SCM}$ 에 $\mathrm{MFCA}$ 방법을 적용하기 위해 코스트의 정의에 따라 분류하고, 조달물류 및 리버스물류에서 정의한 부의 물
류 정의에 따라서 로스를 판별할 수 있다. 이와 같이 $\mathrm{SCM}$ 구성간의 물류활동이 물류영역별 분류에서 무엇 에 해당하는지 파악하고, $\mathrm{SCM}$ 에서 $\mathrm{MFCA}$ 사고방식을 적용한 정의에 따른다면 물류활동에서 발생하는 부의 물류를 보다 쉽게 파악할 수 있다.

\section{4. 결 론}

본 논문에서는 환경부하와 물류원가를 절감할 수 있 는 방안으로서 제조업에서 활용되고 있는 $\mathrm{MFCA}$ 방법 을 $\mathrm{SCM}$ 에 적용하기 위한 연구를 진행하였다.

이를 위해 물류활동에서 발생하는 낭비의 유형을 파 악하고, $\mathrm{SCM}$ 에 $\mathrm{MFCA}$ 의 사고방식을 적용하여 정의 물류와 부의 물류 그리고 물량센터와 코스트의 분류 등을 정의하였다. 또한 정의 물류와 부의 물류를 물류 영역별 분류에 따라 각기 정의하여 $\mathrm{SCM}$ 구성간의 물 류의 영역별 유형에 따라 달리 적용할 수 있도록 하였 다. 정의 물류와 부의 물류를 물류영역별 분류에 따라 각기 정의한 것이 기존 연구와의 차별성이 가장 큰 부 분이다. 이를 통해 리버스물류 등과 같이 물류 흐름의 방향에 따라 정의하게 되면 무조건 낭비로 분류 되는 것을 방지할 수 있다.

향후 연구로는 실무에서 발생하는 보다 많은 물류의 낭비의 유형을 파악하고, 실제 사례 연구가 필요하다.

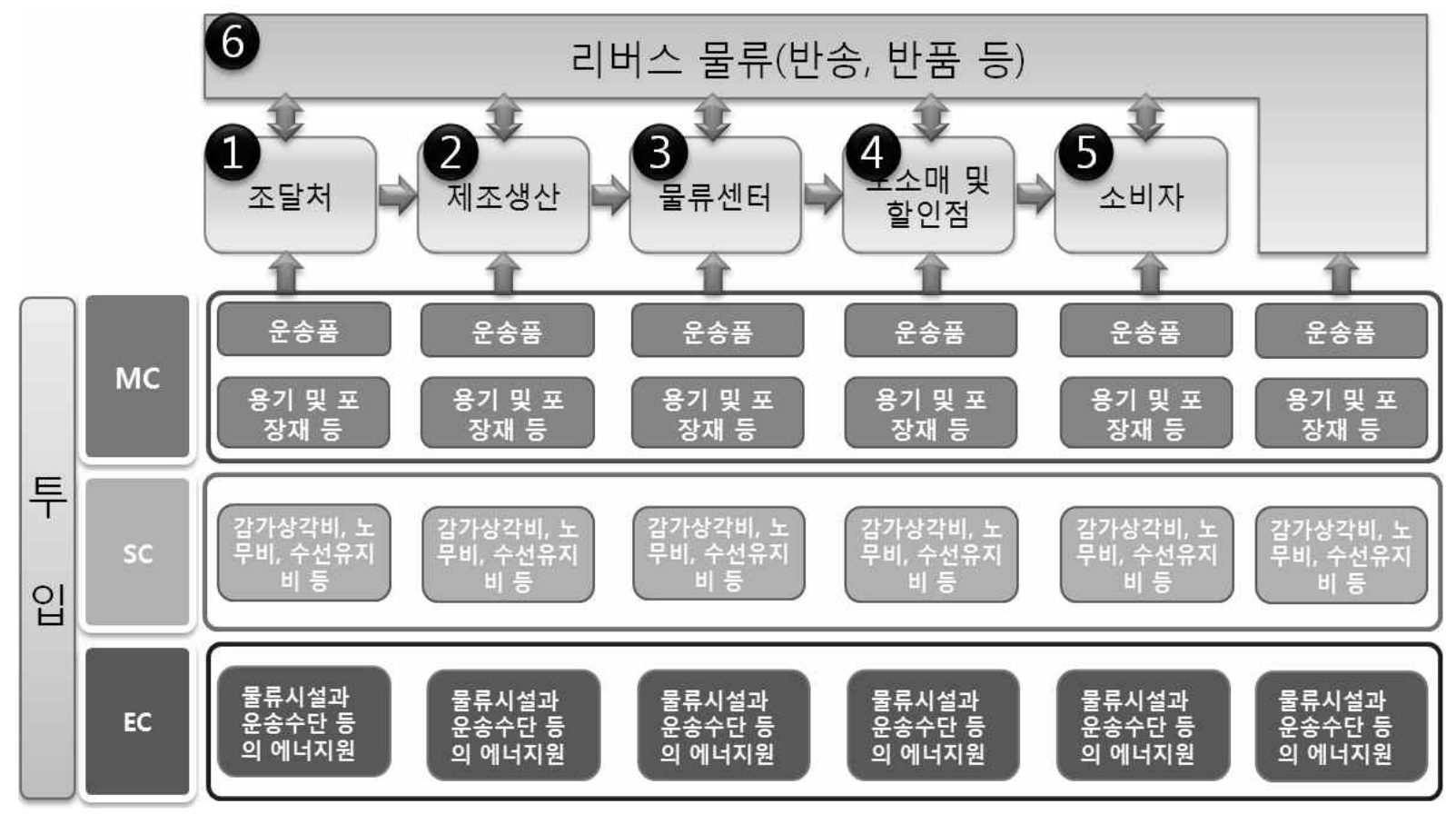

[Figure 8] Conceptual diagram for applying the method of the MFCA in SCM 


\section{References}

[1] 국토교통부, "기업물류비 산정지침", 2012. 08.

[2] 권혁구, 서상범, "2010 국가물류비 산정 및 추이 분 석", 한국교통연구원, 2013. 01.

[3] 김준석, “물류원가관리”, 범한, 2012. 05.

[4] 박석하, "녹색물류비 계산방법과 MFCA 사고방식", 녹색물류학회, 2010. 06.

[5] 서현진, "물류비의 개념, 특질 및 체계", 로지스틱스 연구 제 3 권 제 1 호, 1995. 12.

[6] 신정식, "A Political Proposal for the Reverse Logistics Activation”, 한국유통학회, 2010. 12.

[7] 중소기업청, "물질흐름원가회계(MFCA) 가이드라 인”, 중소기업형 녹색경영기법, 2010. 10.

[8] 한국무역협회 '2011년도 기업물류비 실태조사 보고서', 201305.

[9] Jong-Dae Kim, Mun-Kee Cho, Hyoung-Tae An, Yeon-Bok Kim, "Expansion of Material Flow Cost Accounting Tool to the Supply Chain", Korean Accounting Journal Vol.21 No.2, 2012.05.

\section{저 자 소 개}

장 정 환

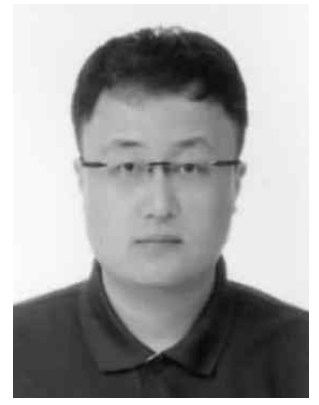

한라대학교 산업경영공학과 공학 사 취득. 인하대학교 대학원 산업 공학과 석사 취득. 현재 동 대학 원 박사과정 중.

관심분야 : RFID 관련 물류 관리 시스템 개발, 항공물류 $\mathrm{RFID}$ 시 스템 개발, 환경물류 등

주소 : 인천광역시 남구 용현동 253 , 인하대학교 산업공학과

장 청 윤

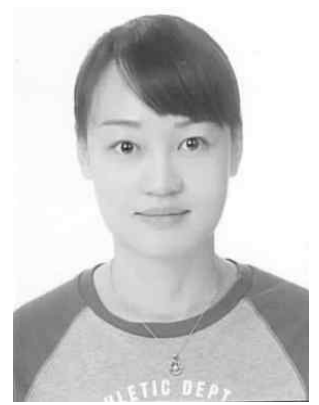

남서울대학교 산업경영공학과 공 학사 취득. 인하대학교 산업공학 과 석사 취득. 현재 동 대학원 박사과정 중.관심분야 : $\mathrm{SCM}$, $\mathrm{ERP}, \mathrm{RFID}$ 관련 물류관리 시스 템 개발 등

주소 : 인천광역시 남구 용현동 253 , 인하대학교 산업공학과
장 승 연

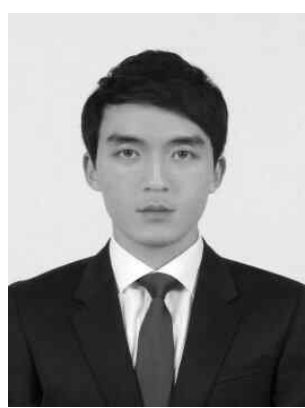

현재 인하대학교 산업공학과 학부 과정 중.

관심분야 : 생산관리, 공정관리, $\mathrm{SCM}$ 등

주소 : 인천광역시 남구 용현동 253 , 인하대학교 산업공학과

조 용 철

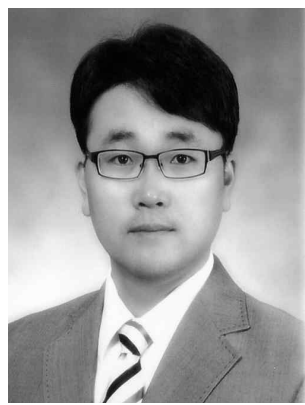

인하대학교 산업공학과 공학사, 공학석사 취득. 동 대학원에서 공 학박사 취득. 현재 한국항만연수 원 인천연수원 교수로 재직 중. 관심분야 : $\mathrm{ERP}, \mathrm{SCM}$, 항만물류, RFID, EPCglobal Network

주소 : 인천광역시 중구 항동 7가 1-31 한국항만연수원 인천연수원

이 현 근

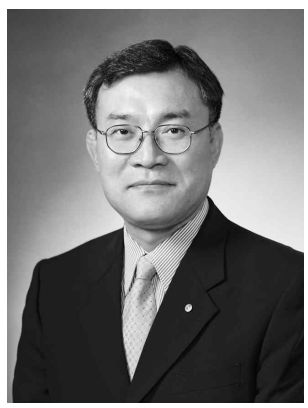

인하대학교 산업공학과 학사 취득. 한국과학기술원 산업공학 과 석사, Tufts 대학 공학석사 취득. 현재 엘비세미콘 고문으로 재직 중

관심분야 : 벤처투자, 창업활성 화, 기술사업화 등

주소 : 경기도 평택시 청북면 율북리 1027-1, 엘비세미콘

이 창 호

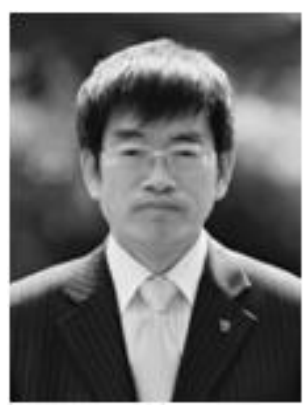

인하대학교 산업공학과 학사 취 득. 한국과학기술원 산업공학과 석사, 경영과학과 공학박사 취득. 현재 인하대학교 교수로 재직 중. 관심분야 : 물류, $\mathrm{RFID}, \mathrm{SCM}$ 등

주소 : 인천광역시 남구 용현동 253 , 인하대학교 산업공 학과 